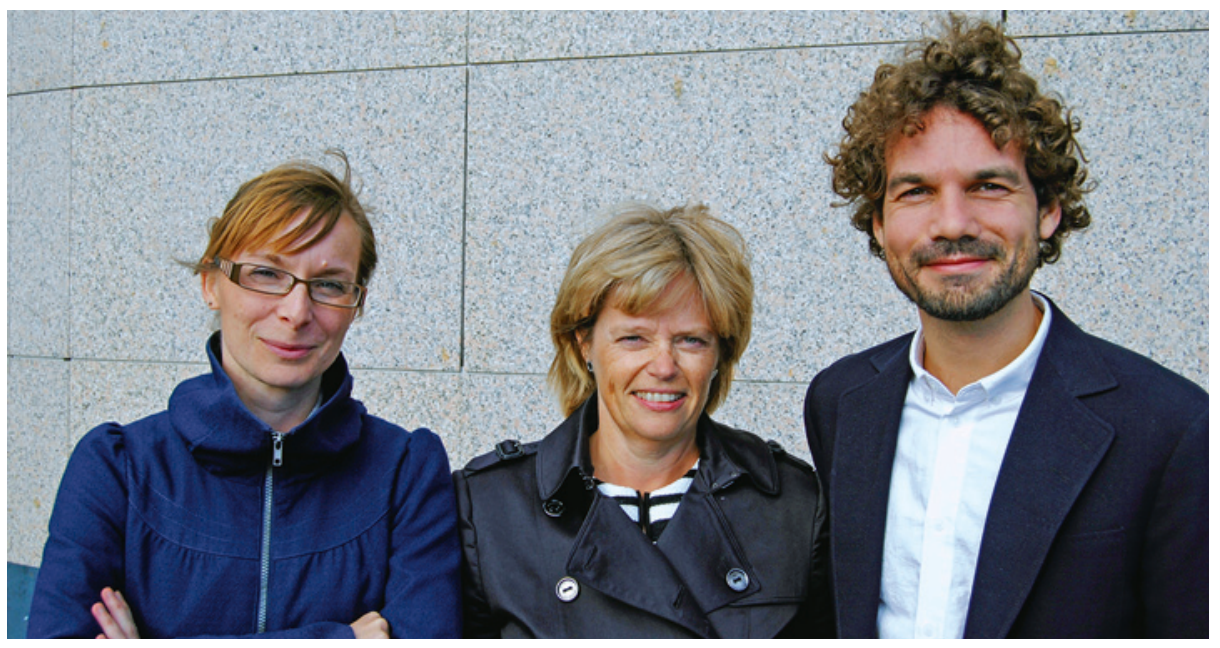

Fra venstre Charlotte Knatten, Kristin Bjørnland og Thomas Fyhn. Foto: Trine Sæther Hagen

\section{Laparoskopi \\ hos barn med spiserørsrefluks?}

Barn som opereres med kikkhullsteknikk for spiserørsrefluks, får oftere tilbakefall enn dem som gjennomgår åpen bukoperasjon.

Laparoskopi benyttes i økende grad fremfor åpen bukoperasjon, såkalt laparotomi, hos barn som trenger abdominalkirurgi. Likevel finnes det få randomiserte studier hvor man har sammenlignet de to operasjonsteknikkene hos barn. I en prospektiv, randomisert studie av barn henvist for spiserørsrefluks, ble dette gjort (1).

Studien omfattet pasienter under 15 år som ble tilbudt antireflukskirurgi ved Oslo universitetssykehus i perioden $2003-09$, til sammen 87 barn. Rundt halvparten av dem hadde nevrologisk sykdom. Alle de laparoskopiske operasjonene ble utført av kirurger med lang laparoskopierfaring. Gjennomsnittlig oppfølgingstid var 3,5 år.

Av de 42 barna som ble vurdert etter laparoskopisk fundoplikasjon, fikk 16 (37\%) tilbakefall av gastroøsofageal reflukssykdom mot 3 av 43 barn (17\%) i laparotomigruppen. Forekomsten av komplikasjoner i løpet av første postoperative måned og liggetid i sykehus var tilnærmet lik i de to gruppene. De aller fleste foreldrene i begge gruppene var svært godt fornøyd med resultatet av operasjonen.

- Forskjellen i residivfrekvens mellom de to operasjonsmetodene er overraskende og viser at man ikke uten videre kan overføre resultater fra studier på voksne til barn, sier Charlotte Knatten og Thomas Fyhn, som er førsteforfattere av studien. - I motsetning til voksne som opereres med fundoplikasjon, er det stor komorbiditet blant barna som opereres med denne metoden, blant annet nevrologisk sykdom og oesophagusatresi. Disse tilstandene er generelt assosiert med økt residivfrekvens. At lapa- roskopisk teknikk gir mindre adheranser enn laparotomi kan være en medvirkende årsak til at laparoskopi gir mer residiv hos barn.

- Forskjellen i residivfrekvens mellom de to operasjonsteknikkene har ført til at kirurger nå diskuterer valg av operasjonsmetode med foreldrene, sier Kristin Bjørnland, som er studiens sisteforfatter. - Spesielt hos svært syke barn hvor residiv og reoperasjon er forbundet med betydelig risiko for barnet, vil både foreldre og kirurger nå ofte foretrekke åpen fundoplikasjon.

\section{Barnekirurgisk forskningsgruppe}

Charlotte Knatten og Thomas Fyhn er tidligere forskerlinjestudenter ved Det medisinske fakultet, Universitetet i Oslo, og jobber nå ved henholdsvis Barnemedisinsk avdeling og Avdeling for gastro- og barnekirurgi ved Oslo universitetssykehus. Overlege og førsteamanuensis Kristin Bjørnland ved Avdeling for gastro- og barnekirurgi, Oslo universitetssykehus, ledet studien. Artikkelen springer ut fra barnekirurgisk forskningsgruppe ved Oslo universitetsog internasjonalt med kirurgisk behandling av gastroøsofageal reflukssykdom og medfødte misdannelser i mage-tarm-kanalen.

\section{Kari Tveito}

Tidsskriftet

\section{Litteratur}

1. Fyhn TJ, Knatten CK, Edwin B et al. Randomized controlled trial of laparoscopic and open nissen fundoplication in children. Ann Surg 2015; 261: $1061-7$. sykehus. Forskningsgruppen jobber nasjonalt
Ordforklaringer

Fundoplikasjon: Operasjon hvor øvre del av magesekken legges rundt nedre del av spiserøret for å hindre at innhold fra magesekken strømmer opp i spiserøret.

Laparoskopi: Kirurgisk teknikk hvor man opererer via små snitt i bukveggen med spesialinstrumenter.

Gastroøsofageal reflukssykdom: Tilbakestrømning av mageinnhold i spiserøret. 